\title{
Home Cries
}

\author{
Kathleen Rockhill
}

\section{Cris de maison}

Relire mon journal qui a servi de soutien en quittant un mariage de convenance. Facile de voir maintenant l'inscription du sujet dans l'hétérosexisme, la socialisation du désir normal(isé). La volonté de faire ma vie mieux que celle de ma mère. La révolte du corps, les coups de pieds qui me propulsent hors du mariage en réincarnation de la Nora d'Ibsen. Toute cette rage et cette joie inserrées entre les couvertures de soie de ce journal, les incidences répétés sans fin en encre bleu, vert, noir... Le travail de la mémoire pour (re)construire une vie, une histoire à travers la force de la loi. La mémoire qui forge le récit de ma vie, la mémoire empreinte de la nostalgie d'une maison pleine d'amour interrompu par des souvenirs de la révolte de la mauvaise fille, révolte qui ordonne tout en opposition, en binaires rigides. Un dé/membrement longtemps avant un ré/membrement. La rage. Au coeur, une histoire d'inceste. La mauvaise mère condamnée avec le père incestueux par la fille qui cherche à devenir "la mère parfaite." La mémoire, une clé de "la vérité." Mais comment m'en servir? La mémoire est toujours contrainte. Avec quoi et en présence de qui est-ce que le travail de la mémoire se fait? Car ce travail est reglé par l'opposition du privé/du public qui établit les normes du dicible, voire du pensable. Car plus l'on poursuit le travail de la mémoire, plus l'on se rend compte de la régulation des émotions par la normalisation du pouvoir. Le travail de la mémoire cherche à exposer comment le pouvoir circule dans nos corps et nos émotions, dans le quotidien, l'intime. Ce que je cherche à faire dans ce travail de la mémoire que je poursuis avec ma vie et que j'enseigne dans mes classes à l'université est d'amener ces luttes émotives vers la scène publique pour les analyser, pour déjouer la dynamique du privilège et de l'oppression épistémique où nos peurs et nos désirs sont reproduits. La mémoire qui forge la résistance à force des ré/visions constantes. 
The quality of light by which we scrutinize our lives has direct bearing upon the product which we live, and upon the changes which we hope to bring about in those lives. - Audre Lorde

Who am I besides a bundle of picture book longings? The reincarnation of Nora in A Doll's House? "I feel ephemeral... unreal. . . maybe if I write in this notebook everyday, I'll at least know I exist." Can I capture the mad mutterings of my mind, the warring voices that tear me apart? If I can get it all down in black and white, will I discover the truth? Who I am? Legs spread out before me at last, out there, where I can see her, read her, touch her, know her...real, like a book.

\section{$* * * * *$}

With these thoughts I begin my journal. Endless repetition. Warring voices, emotion... harnessed between the lines, the pages, every page filled from top to bottom, side to side, no corner empty of the precisely penned script...inks of blue, green, black, write rage, elation, fear, desire. There I am, neatly folded between the lovely silk embroidered covers of my journals. The self I am ashamed of...the self I long to be... the self I am determined to change.

I will...I will do it differently... have a career, raise my children, build a happy home... I will not offend my husband's masculinity the way my mother emasculated my father. The man I marry feels as safe as white bread. Sex like clockwork, every other night. I do my wifely duty, feign orgasm - not too much to ask - it only lasts five or ten minutes. In no way will I emasculate this man. I will do it right. Perfectly.

The thin fabric that is my life begins to unravel.

Alcohol does not preserve. The armour that has held me together all these years cannot protect me from the volcanic eruptions that take me over. Who is that woman lying on the bed - on the couch...kicking, screaming, shaking, flailing? "Don't! Don't touch me! Go away! Leave me be. Get away...Get away from meee!!" She can't stop her body's shaking anymore than she can stop the nightmare that comes to her night after night: She's being buried alive; standing above her, surrounding 
her open grave, are her mother, her father, her brothers, her husband...they shake their heads sadly as they pass the shovel from one to the other, oblivious to the muffled cries that come from below....

I leave my marriage of ten years - a marriage of abortion, born of pregnancy when there was little choice - give up the child for adoption or marry the father. Why did I never think of rearing him on my own? So easy to see now, the social construction of choice, conscription into heterosexism; normalcy of desire - to be a wife, a mother, and, above all, do it better than my mother. Loveless marriages united by woman's guilt, shame, gratitude, longing, determination.

Through intricate webs of regulation, I (re)construct my history, my experience. Memory, crafted to provide a mythology through which I make sense of my life. Memory, resonant with nostalgic longings for home, for safety, for love and acceptance; memory resonant with rebellion - the bad girl or the perfect wife; memory resonant with the determination to overcome the effects of incest upon my life. In my rebellion, I become rigid...essentializing, objectifying, homogenizing, reifying...moulding into a solid mass all to which I stand in opposition. In raging pain, I dis / membered long before I could re/member.

I look back through my journals, study the landscapes of my subjectivity, to figure out how, or if, I have changed. My rebellions feel endlessly caught up in new conformities. I shudder at how I once set my mother up as the one responsible for my father's violation of me. In spite of my determination to be different, just as I held my mother responsible, so too, I held myself responsible - to provide a perfect home - a safe, loving home - for my children. Unthought, this sense of responsibility stands in contradiction to my feelings of nonexistence, of nonagency, of irresponsibility. I leave my marriage only when "taken over" by madness, by nightmares I cannot control. Ashamed of my frigidity, I hunger to be man's sexual desire, and long - oh how Ilonged - for sexual fulfillment.

Feminism provides a lens through which I learn to (re)interpret my experience; I begin to see my heterosexualization. In the non/sense of my self, I re/member myself as victim. With other white feminists, I 
forge an identity in opposition to dominant constructions of "Woman." Years later, when I am comfortable in claiming my identity as a lesbian, I am horrified at the extent to which my rebellions have been framed through heterosexism.

Challenges by women of colour push me to see how I have interpreted my history through the lens of incest, constructing myself as a heroic victim. I don't want to minimize the ravages of incest, but it is not the whole story. It is hard for me to see my privilege; race is nowhere present in the story I tell, in the memories through which I shape my identity.

My father's death this last week pushes me yet further to see how I have constructed my self in opposition to him. (This neatly controlled script erases the pain of these pushes.) I cannot bear to admit to my objectification - and monsterization - of him. Unable to find our way through openness, through sustained confrontation, through acceptance of the irreconcilable, we could not look each other in the eye. My painfilled memories are forced underground; I am tagged as the "negative one," holding my family hostage with my bad memories. I refused to forget the violence. I could not remember the love.

It takes my father's being in a coma to open the tall wrought-iron gates that have enclosed my heart all these years; to feel safe as I stroke his body, his forehead, his heart, his feet, his hands - those strong hands that once held the potential for so much violence/so much love. Home at last safe with him in my arms, I cry out for the love we could not realize. A love crippled by his betrayal of my trust/my betrayal of his law that I must "forgive and forget." Resistance to the law of forgiveness, so crucial to my survival, crumbles at his death as I cry out in agony "forgive me, oh Dad, forgive me." I cannot believe my ears, and yet I know the yearning that tears at my heart.

In my grief, I torment myself anew. How can I write this? How dare I violate his memory?...Me, the violent one, for remembering, for reminding....

Breaking silences, telling our tales, is not enough. - Adrienne Rich

Memory. The key to "truth," the only available proof, for incest survivors. For most of my life I have pushed myself to remember, as though, through memory, I could capture the quintessential experience 
that would justify my anger/make sense of the violence in my life. Now, I wonder. As I reflect upon my history, I feel an imperative, in what I $\mathrm{re} /$ member, to wipe away the contradictions that otherwise paralysed me, to form a foundation upon which to stand, to feel OK about my life, to conceal the shame that lurks within. I forged a coherent, comprehensible identity in opposition to my oppression - a heroic victim, oblivious to the possibility of my power.

There is no essential experience, waiting to be remembered. Memory is influenced by the context, the conditions, of remembering - by our investments in what we remember/what we forget. The stories I construct about my life, fixed in the pages of my journals, are interpretations, in need of interpretation.

Endless possibilities, limited all ways by the explanatory discourses available to us, discourses through which we filter our experiences. These discourses are embodied, circulating through intimate, authoritative relationships that matter to us, subtly defining our fears and desires, coercing our conformity through the taken-for-granted normative practices of everyday life. The maxim, for example, that I "forgive and forget," is sedimented through my longings for love, as well as the everyday practices that socially exclude tabooed memories. Memories that challenge dominant mythologies are forced underground, through a politics of speech and silence.

We are constantly faced with constraints upon what can be remembered, in the presence of whom. These constraints sediment the public/private divide. When I transgress that divide, I run into the regulation of the speakable, which I experience breathlessly, as a knot in my gut, the cold grip of fear around my heart. I trace the words that haunt me - traitor, hypocrite, cruel - to break their regulatory chains, to track the materiality of my fears. I struggle with the emotional and material investments that make me vulnerable to regulation, and sometimes choose to follow a politics of silence. These choices are deeply troubling.

In the imperative to speak, to speak from experience, to re/member, I struggle to find ways to work with the differential risks of self-exposure, the complex power relationships that are always in play, the paradox of experience as a site of regulation and resistance. I think of a graduate course I teach, in which I encourage participants - all women, mostly white - to work from their experiences, their memories, bringing these 
into a critical dialogue with feminist theories of oppression. Memories are, quite literally, worked, to expose how power circulates in its most localized, visceral forms...in our various strivings to attain "normalcy"...in our desires to be special, in our fear of being ordinary....in contradictory rules of proper conduct, of morality...in our desire for love, our fear of being the outsider...in the concrete actions and relationships that make up the structures of our lives.

How are we taught - how do we appropriate - the dance of the dominated/dominator? How are we differently located as partners/opponents in that dance? In my work, my goal has been to move this dance from the private stage of our paralysing emotional struggle with good/bad, to the public stage of analysis and action, as we come to grips with how we are variously inscribed through our fears and longings, through our ignorances, to reproduce the dynamic of privilege/oppression.

This work is fraught with difficulties. Our emotional attachments are often in contradiction to our more progressive beliefs. Still, it is possible to scrutinize our emotions, to analyze them as effects of regulation that conceal and congeal power relations, setting up "shoulds" that divide us against ourselves. I think of my struggles against the regulatory norms of forgiveness, loyalty, responsibility...I agree with Sandra Lee Bartky that we need to examine "the role of emotion, most particularly of the emotions of self-assessment, both in the constitution of subjectivity and in the perpetuation of subjection" (98).

It is not easy to look critically at our emotional attachments. To analyze that which we experience as intensely private and personal can be a painfully alienating experience. We are used to "confiding," or "confessing;" we expect support. We don't welcome having our cherished beliefs, assumptions, ways of being, sense of self, challenged. We cave in to guilt, shame, denial. It is difficult to move beyond thinking of ourselves as good or bad, to see the ideological practices at work in the construction of our subjectivities, in the production of subjection. The ethic of support, our fear of judgement - works against critique. We don't want to hurt/be hurt. Ironically, our difficulty in distancing ourselves enough to see how regulation works through our emotions demonstrates the effectiveness of regulation in privatizing and individualizing dominating practices as our singular badness/shame. 
....my memory and my experience of a safe place to be was based on places secured by omission, exclusion or violence, and on my submitting to the limits of that place. - Minnie Bruce Pratt

We run head-first into our attachment to memory, to our experience, as unchallengeable..."I know because I have lived it," is the common refrain. True...but how are you framed/ how do you frame? For the most part, we turn to the excavation of our memories because we want to legitimize our interpretation of our lives, our day in, day out, resistance. For so many of us, the embrace of feminism has meant the loss of home, of loved ones, of life as we have known it. We turn to our memories to construct new homes, new identities, where we can feel safe and strong. We cry out for home.

To be met by a theory of experience that challenges its sanctity as truth is extremely disconcerting. True or false is not the point. What are the clues that experience can provide to the regulatory chains that construct our subjectivities? This theory of experience, as ideologically formed, is difficult to accept. Does this mean that there is not a place of knowing that is outside of discourse? What about the unconscious? Emotions? Body memory? Resistance?

Consider the apparently contradictory positions of Frigga Haug and Uma Narayan: Haug argues that our experience is organized to unname domination; that the invisibility of the social order is an effect of socialization; in contrast, Uma Narayan speaks of the "epistemic privilege of the oppressed," who have an emotional knowledge of how domination works in its most localized, everyday forms, because they have lived it.

I find both positions compelling; both "true," both incomplete. We contain, within our consciousness, contradictory knowledges, competing beliefs, untheorized experiences. We are more or less critically conscious of how domination works, depending upon our subject position, our access to competing discursive fields. The closer we are to what Audre Lorde calls the "mythical norm" (interesting how what gets set up as superior is passed off as the norm), the greater our investment in not seeing how domination works; the more likely we are to be seduced by the possibility of acceptance/love if we conduct ourselves according to its rules. In contrast, the further away we are from the "mythical norm," the more likely we are to be rejected as candidates for acceptance into its world - and the more likely we are to find "home" in oppositional, 
marginalized worlds. I would modify Frigga Haug's theory to say that experience - particularly of the privileged - is organized to unname domination; and I would modify Narayan's theory to say that, depending upon how critically experience is interpreted, the oppressed have epistemic privilege. Insofar as we occupy multiple subject positions, we live the complicated dynamics of both privilege and oppression.

Where I have worked with groups to critique our experiences, differential knowledges, born of our differing subject positions, are highly conflictual. The hard "truth" of both Narayan's and Haug's theories is manifest in group polarization according to location in relation to the "mythical norm," and how much work a person has done to look at internalized dominance. Who has the right to critique whose experience? Are some experiences more valid than others? Whose experience counts? Can we use our experiences of oppression to become more aware of how we may participate in the (re)production of privilege?

I want to reframe these conflicts, to look at them as evidence of the effectiveness of dominating practices, get our emotions out on the table where we can dissect them. I wish we could sustain conflict, embrace the irreconcilable. I feel my small, painful, lifelong struggle with incest played out on a much larger social scale. I run up against subjection, like a maze of invisible concrete walls, in the "shoulds" with which I struggle. To interrupt the agenda of the agenda-setter, is to be met with ridicule, marginalization, exclusion. Agenda are not designed to create social spaces of ambiguity and dissent; spaces that embrace "the negative," including objectification and anger as integral to resistance, as necessary counters to the eradications of power. Subjection works through a series of emotional binarisms - love or hate-agree or disagree - be pleasant or go away - that force "the negative" underground.

TWA doesn't sell tickets / to underground memories / tender and vulnerable to the world. - Margaret Randall

I don't want Trans World Airlines to sell tickets. I don't want the vultures to pick at my fragile truths, exposing them to the harsh glare of the all-consuming tourist. I want to choose my audience, to control how my memories get used. And I cannot.

I long to build a new home of harmonizing perfection, where I can rest 


\section{Tessera}

my weary broken bones. Erase ambiguities, contradictions, conflicts. I write "resistance requires constant revision"... what Minnie Bruce Pratt refers to as the "expansion of the constricted eye." Yes...And it is time to rest.

\section{Works Cited}

Bartky, Sandra Lee. Femininity and Domination. New York: Routledge, 1990.

Haug, Frigga. Beyond female masochism: Memory-work and Politics. London: Verso, 1992.

Lorde, Audre. "Poetry is not a luxury" in Sister Outsider. Trumansburg, New York: The Crossing Press, 1984. 36.

Narayan, Uma. "Working Together across Difference: Some Considerations of Emotions and Political Practice." Hypatia 3 (2), 31-47.

Pratt, Minnie Bruce. "Identity: Skin Blood Heart" in Yours in Struggle, ed. E. Bulkin, M.B. Pratt, B. Smith. Brooklyn: The Long Haul Press, 1984. Randall, Margaret. This is About Incest. Ithaca, New York: Firebrand Books, 1987.

Rich, Adrienne. "Resisting Amnesia and Personal Life" in Blood, Bread and Poetry. New York: W.W. Norton, 1986. 